\title{
Synthesis of silene spaced divinyl naphthalene copolymers
}

\author{
Moturu V. R. K. Murthy and Tien-Yau Luh* \\ Department of Chemistry, National Taiwan University, Taipei, Taiwan 106 \\ E-mail: tyluh@ccms.ntu.edu.tw
}

\section{Dedicated to Prof. T. R. Govindachari on the occasion of his $85^{\text {th }}$ birthday \\ (received 23 Mar 01; accepted 25 Sep 01; published on the web 03 Oct 01)}

\begin{abstract}
A convenient procedure for the preparation of 2,6-bis[(2-dimethylsilyl)vinyl]naphthalene 1 and 2,6-(bis-ethynyl)naphthalene 2 are reported. Reactions of 1 and $\mathbf{2}$ in the presence of $\mathrm{RhCl}\left(\mathrm{PPh}_{3}\right)_{3}$ give the corresponding copolymer $\mathbf{3}$ at different $\mathrm{Mn}$ depending on the reaction conditions.
\end{abstract}

Keywords: Silylene spaced copolymers, divinyl naphthalene copolymers

\section{Introduction}

Conjugated polymers are known to exhibit diverse optoelectronic properties. ${ }^{1-3}$ A polyphenylene-vinylene based device has been shown to serve as a light emitting diode. ${ }^{4}$ Introduction of spacers between well-defined chromophores in the polymeric backbone can occasionally increase the processibility and in the mean time, the emission wavelength can be predicted. ${ }^{5,6}$ Silylene moiety appears to be an attractive spacer for this purpose. ${ }^{6}$

As part of our continuing interest on the structure activity investigation on the photophysics of silylene-spaced divinylarene copolymers, ${ }^{7-11}$ we report here the synthesis of the precursors $\mathbf{1}$ and $\mathbf{2}$ and the corresponding silylene-spaced divinyl naphthalene copolymers $\mathbf{3}$.

\section{Results and Discussion}

The methyl ester of 6-hydroxy-2-naphthoic acid 4 was converted into triflate 5 upon treatment with triethylamine and triflic anhydride in THF. ${ }^{12}$ Palladium catalyzed carbonylation in methanol ${ }^{13}$ afforded 6 in $68 \%$ yield. The aldehyde 8 was prepared by refluxing a THF solution of 6 with an excess LAH to furnish the alcohol 7, which after treatment with manganese dioxide yielded $72 \%$ of the corresponding 2,6-diformylnaphthalene 8 . Reaction of 8 with 1,2ethanedithiol in the presence of boron trifluoride diethyl etherate gave the naphthalene-2,6-bisdithioacetal 9 with a yield of $88 \%$. The vinyldimethylsilane 10 was synthesized from the bis- 
dithioacetal 9 and $\mathrm{Me}_{2}\left({ }^{\mathrm{i}} \mathrm{PrO}\right) \mathrm{CH}_{2} \mathrm{MgCl}$ in the presence of $5 \mathrm{~mol} \% \mathrm{NiCl}_{2}\left(\mathrm{PPh}_{3}\right)_{2}{ }^{14}$ The crude product of $\mathbf{1 0}$ was directly used for the next step. Reduction of the Si-O bond was achieved by treatment of $\mathbf{1 0}$ with an excess of LAH to yield 43\% (from 9) of the monomer $\mathbf{1}$ (Scheme 1).
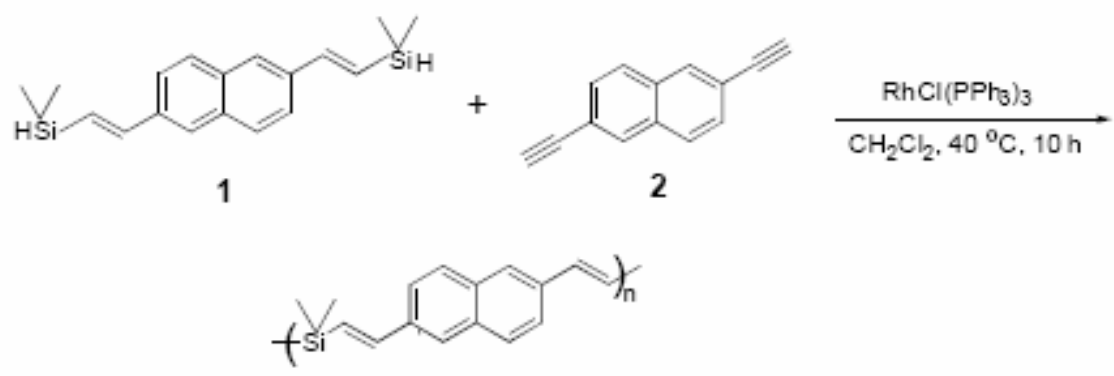

3

2,6-Dialkynylnaphthalene 2, was conveniently synthesized in three steps from naphthalene2,6-diol (11) (Scheme 2). A THF solution of compound $\mathbf{1 1}$ was treated with triflic anhydride in the presence of triethylamine to yield the corresponding ditriflate 12. Sonogashira reaction ${ }^{15}$ of 12 led to the 2,6-bis[(trimethylsilyl)ethynyl] naphthalene (13) with a yield of 93\%, which after treatment with potassium carbonate gave $91 \%$ of 2,6-(bis-ethynyl)naphthalene (2).
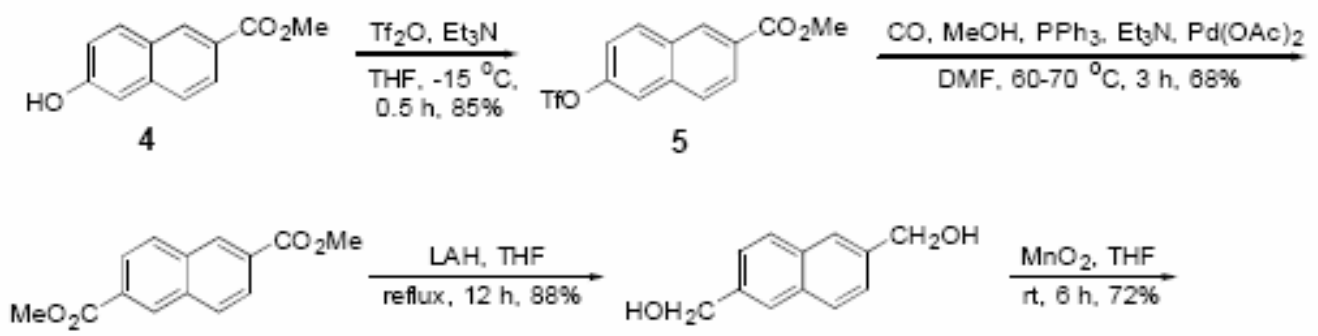

6

7
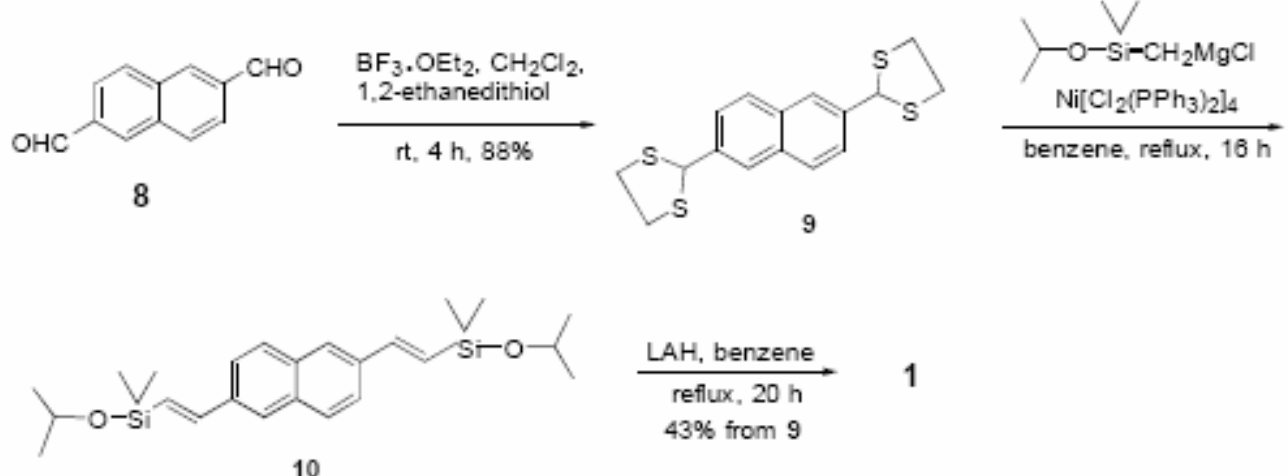

\section{Scheme 1}




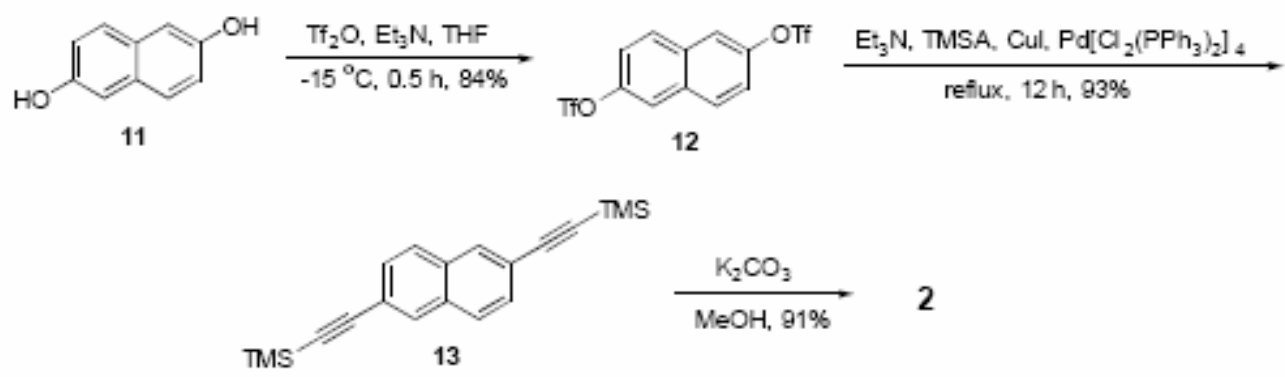

Scheme 2

The reaction of 2,6-bis[2-(dimethylsilyl)vinyl]naphthalene $\mathbf{1}$ and the 2,6diethynylnaphthalene (2) in the presence of a catalytic amount of $\mathrm{RhCl}(\mathrm{PPh})_{3}$ led to the copolymer $3\left(M_{n}=2600\right.$; PDI 2.5) with a yield of $61 \%$. An increase of the concentration of the catalyst gave the copolymer 3 in $53 \%$ yield $\left(M_{n}=4500\right.$; PDI 3.3).

\section{Experimental Section}

Methyl 6-hydroxy-2-naphthoate (4). Concentrated sulfuric acid (2 mL) was added to a methanolic solution of 6-hydroxy-2-naphthoic acid $(50.0 \mathrm{~g}, 266 \mathrm{mmol})$. The solution was refluxed for $12 \mathrm{~h}$. Then the solution was cooled to $\mathrm{rt}$ and the crude 4 was precipitated from the solution. After filtration the crude product was added to a $5 \% \mathrm{NaHCO}_{3}$ solution and stirred for $0.5 \mathrm{~h}$. The solid was filtered, washed several times with water and dried in vacuum to give 4 (47.0 g, 88\%); mp 157-158 ${ }^{\circ} \mathrm{C}$ (EtOAc-hexane); (Lit. ${ }^{16} \mathrm{mp} 158-159^{\circ} \mathrm{C}$ ).

6-Methoxycarbonyl-2-naphthyl triflate (5). Triflic anhydride $(12.5 \mathrm{~mL}, 74.3 \mathrm{mmol})$ was added to a cooled solution $\left(-15^{\circ} \mathrm{C}\right)$ of $4(10.0 \mathrm{~g}, 49.5 \mathrm{mmol})$ and $\mathrm{Et}_{3} \mathrm{~N}(20.5 \mathrm{~mL}, 148 \mathrm{mmol})$ in THF $(100 \mathrm{~mL})$. After stirring for $0.5 \mathrm{~h}$ at the same temperature, water was added and the mixture was extracted with $\mathrm{Et}_{2} \mathrm{O}$. The organic phase was separated, washed with an ice-cold $1 \%$ aqueous $\mathrm{NaOH}$ solution, water and brine and evaporated to yield $5(14.0 \mathrm{~g}, 85 \%)$ as a white solid; mp $70-71{ }^{\circ} \mathrm{C}\left(\mathrm{CHCl}_{3}\right.$-hexane). IR (KBr): v 3010, 2920, 1719, 1442, 1429, 1298, 1252, 1208, 1150 , 962, 924, 874, 817, $610 \mathrm{~cm}^{-1}$; ${ }^{1} \mathrm{H}$ NMR (400 MHz, $\mathrm{CDCl}_{3}$ ): $\delta 3.97$ (s, $3 \mathrm{H}$ ), 7.41 (dd, J=9.2, 2.2 $\mathrm{Hz}, 1 \mathrm{H}), 7.76$ (d, $J=2.2 \mathrm{~Hz}, 1 \mathrm{H}), 7.89$ (d, $J=8.8 \mathrm{~Hz}, 1 \mathrm{H}), 8.01$ (d, $J=9.2 \mathrm{~Hz}, 1 \mathrm{H}), 8.13$ (dd, $J=8.8,1.4 \mathrm{~Hz}, 1 \mathrm{H}), 8.61(\mathrm{~s}, 1 \mathrm{H}) ;{ }^{13} \mathrm{C} \mathrm{NMR}\left(100 \mathrm{MHz}, \mathrm{CDCl}_{3}\right): \delta 52.4,118.7(\mathrm{JC}-\mathrm{F}=319 \mathrm{~Hz})$, $119.2,120.5,126.9,128.3,128.8,130.8,131.4,132.1,135.5,148.6,166.6 ; \mathrm{MS} \mathrm{m} / \mathrm{z}(\%) 334$ (66) $\left[\mathrm{M}^{+\bullet}\right.$ ], 201 (76), 173 (100), 142 (36), 114 (33); HRMS Calcd for $\mathrm{C}_{13} \mathrm{H}_{9} \mathrm{~F}_{3} \mathrm{O}_{5} \mathrm{~S}$ : 334.0123; Found: 334.0125; Anal. Calcd for $\mathrm{C}_{13} \mathrm{H}_{9} \mathrm{~F}_{3} \mathrm{O}_{5} \mathrm{~S}: \mathrm{C}, 46.71 ; \mathrm{H}, 2.71$. Found: C, 46.83; H, 2.50 .

Dimethylnaphthalene-2,6-dicarboxylate (6). A mixture of 5 (11.0 g, $32.9 \mathrm{mmol}), \mathrm{Et}_{3} \mathrm{~N}(9.1$ $\mathrm{mL}, 65.8 \mathrm{mmol}), \mathrm{Pd}(\mathrm{OAc})_{2}(0.74 \mathrm{~g}, 3.28 \mathrm{mmol}), \mathrm{PPh}_{3}(0.55 \mathrm{~g}, 2.09 \mathrm{mmol})$ and $\mathrm{MeOH}(26 \mathrm{~mL}$, $650 \mathrm{mmol})$ in DMF $(100 \mathrm{~mL})$ was purged with $\mathrm{CO}$ for $5 \mathrm{~min}$ and stirred under a $\mathrm{CO}$ atmosphere $(1 \mathrm{~atm})$ for $3 \mathrm{~h}$ at $60{ }^{\circ} \mathrm{C}$. Then the reaction mixture was cooled to $\mathrm{rt}$, treated with brine and 
extracted with $\mathrm{Et}_{2} \mathrm{O}$. The organic layer was washed with water, ice-cold $1 \mathrm{~N} \mathrm{HCl}$ and brine, dried with $\mathrm{Na}_{2} \mathrm{SO}_{4}$ and evaporated to dryness to yield $6(5.5 \mathrm{~g}, 68 \%)$ as a colorless solid. mp 185-186 ${ }^{\circ} \mathrm{C}(\mathrm{MeOH})$; (2it. $\left.{ }^{17} \mathrm{mp} 186-187^{\circ} \mathrm{C}\right)$.

2,6-Bis-hydroxymethylnaphthalene (7). A mixture of 6 (4.4 g, $18.0 \mathrm{mmol})$ and LAH (3.0 g, $78.9 \mathrm{mmol})$ in THF $(100 \mathrm{~mL})$ was refluxed for $12 \mathrm{~h}$. The reaction mixture was cooled to $\mathrm{rt}$ and the excess LAH was quenched by a slow addition of water. The precipitate was filtered and the filtrate was extracted with $\mathrm{Et}_{2} \mathrm{O}$. The organic layer was washed with water and brine and dried with $\mathrm{Na}_{2} \mathrm{SO}_{4}$. After evaporation, the crude product was crystallized from EtOH to yield 7 (3.0 g, $88 \%$ ) as colorless crystals; mp $168-169^{\circ} \mathrm{C}$; (Lit. ${ }^{18} \mathrm{mp} 169-170{ }^{\circ} \mathrm{C}$ ).

2,6-Diformylnaphthalene (8). A THF $(75 \mathrm{~mL})$ solution of $7(3.0 \mathrm{~g}, 16.0 \mathrm{mmol})$ was treated with $\mathrm{MnO}_{2}(8.30 \mathrm{~g}, 95.43 \mathrm{mmol})$ at $\mathrm{rt}$ for $6 \mathrm{~h}$. Then the reaction mixture was filtered through a celite pad. After evaporation, the crude product was crystallized from $\mathrm{CHCl}_{3}-\mathrm{MeOH}$ to yield 8 (2.1 g, $72 \%$ ) as colorless crystals; mp $173-175^{\circ} \mathrm{C}$; (Lit. ${ }^{19} \mathrm{mp} 174-176^{\circ} \mathrm{C}$ ).

2,6-Bis(1,3-dithiolan-2-yl)naphthalene (9). Into a stirred solution of 8 (2.0 g, $10.87 \mathrm{mmol})$ and boron trifluroide diethyl etherate $(0.5 \mathrm{~mL}, 3.87 \mathrm{mmol})$ in $\mathrm{CH}_{2} \mathrm{Cl}_{2}(30 \mathrm{~mL})$ was added 1,2ethanedithiol $(2.1 \mathrm{~mL}, 24.5 \mathrm{mmol})$ and stirring was continued at $\mathrm{rt}$ for $4 \mathrm{~h}$. Then the reaction mixture was poured into an aqueous $10 \% \mathrm{NaOH}$ solution. The organic phase was separated and the aqueous layer was extracted with $\mathrm{CH}_{2} \mathrm{Cl}_{2}$. The combined organic layers were washed with a $10 \% \mathrm{NaOH}$ solution $(4 \times 30 \mathrm{~mL})$ and brine, dried with $\mathrm{Na}_{2} \mathrm{SO}_{4}$ and evaporated to yield 9 (3.2 g, $88 \%)$ as a colorless solid; mp $150-152{ }^{\circ} \mathrm{C}\left(\mathrm{CHCl}_{3}\right.$-hexane); IR (KBr): $v 2922,1719,1507,1432$, 1425, 1350, 1278, 1244, 1211, 1144, 899, 821, 756, $484 \mathrm{~cm}^{-1} ;{ }^{1} \mathrm{H}$ NMR $\left(400 \mathrm{MHz}, \mathrm{CDCl}_{3}\right): \delta$ 3.36-3.42 (m, $4 \mathrm{H}), 3.49-3.55$ (m, $4 \mathrm{H}), 5.78(\mathrm{~s}, 1 \mathrm{H}), 7.65(\mathrm{~d}, J=8.4 \mathrm{~Hz}, 2 \mathrm{H}), 7.75(\mathrm{~d}, J=8.4$ $\mathrm{Hz}, 2 \mathrm{H}), 7.83$ (s, $2 \mathrm{H}) ;{ }^{13} \mathrm{C} \mathrm{NMR}\left(100 \mathrm{MHz}, \mathrm{CDCl}_{3}\right): \delta 40.4,56.4,126.3,126.4,128.5,132.6$,

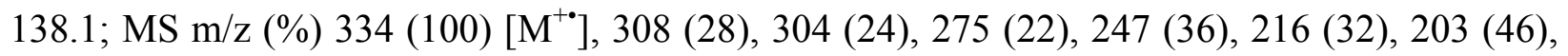
185 (26), 171 (34), 84 (18); HRMS Calcd for $\mathrm{C}_{16} \mathrm{H}_{16} \mathrm{~S}_{4}$ : 336.0135; Found: 336.0134; Calcd for $\mathrm{C}_{16} \mathrm{H}_{16} \mathrm{~S}_{4}:$ C, 57.10; H, 4.79. Found: C, 57.03; H, 4.80.

2,6-Bis\{2-[dimethyl(isopropoxy)silyl]vinyl\}naphthalene (10). A catalytic amount of 1,2dibromoethane was added to flame dried magnesium $(2.0 \mathrm{~g}, 83.3 \mathrm{mmol})$ in THF $(5 \mathrm{~mL})$. To this mixture, a solution of $\mathrm{Me}_{2}(\mathrm{PrO}) \mathrm{SiCH}_{2} \mathrm{Cl}(15.1 \mathrm{~mL}, 83.3 \mathrm{mmol})$ in THF $(15 \mathrm{~mL})$ was added dropwise and stirred until all magnesium had been reacted. Then the THF was evacuated as much as possible to give $\mathrm{Me}_{2}(\mathrm{PrO}) \mathrm{SiCH}_{2} \mathrm{MgCl}$ which was dissolved in benzene $(50 \mathrm{~mL})$ and transferred through a canula into a solution of $9(2.8 \mathrm{~g}, 8.33 \mathrm{mmol})$ and $\mathrm{NiCl}_{2}\left(\mathrm{PPh}_{3}\right)_{2}(0.27 \mathrm{~g}$, $0.41 \mathrm{mmol})$ in benzene $(100 \mathrm{~mL})$. The mixture was refluxed for $20 \mathrm{~h}$, cooled to $\mathrm{rt}$ and an aqueous $\mathrm{Na}_{2} \mathrm{CO}_{3}$ solution was added. The organic layer was separated and the aqueous layer was extracted twice with $\mathrm{Et}_{2} \mathrm{O}(50 \mathrm{~mL})$. The combined organic layers were washed with an aqueous solution of $10 \% \mathrm{NaOH}(2 \times 30 \mathrm{~mL})$ and brine and dried with $\mathrm{Na}_{2} \mathrm{SO}_{4}$. After evaporation the residue was distilled under reduced pressure to give 10 (7.0 g) as a viscous liquid, which was directly used for the next step without further purification.

2,6-Bis[(2-dimethylsilyl)vinyl]naphthalene (1) A benzene $(100 \mathrm{~mL})$ solution of crude 10 (7.0 $\mathrm{g}, 17.0 \mathrm{mmol})$ and $\mathrm{LAH}(2.6 \mathrm{~g}, 68.4 \mathrm{mmol})$ was heated for $20 \mathrm{~h}$ at refluxing temperature. Then 
the reaction mixture was cooled with an ice-bath and the excess LAH was quenched by a slow addition of water. The precipitate was filtered; the organic layer was washed with brine and dried with $\mathrm{MgSO}_{4}$. After evaporation the residue was purified by column chromatography (silica gel, hexane) to yield 1 as colorless needles (1.1 g, 43\% two steps) mp 102-104 ${ }^{\circ} \mathrm{C}$ (hexane); IR (KBr): v 3070, 2962, 2929, 2118, 1696, 1250, 1050, 988, 893, 830, $814 \mathrm{~cm}^{-1}$; ${ }^{1} \mathrm{H}$ NMR $(300$ $\left.\mathrm{MHz}, \mathrm{CDCl}_{3}\right): \delta 0.25(\mathrm{~d}, J=3.7 \mathrm{~Hz}, 12 \mathrm{H}), 4.22-4.24(\mathrm{~m}, 2 \mathrm{H}), 6.56(\mathrm{dd}, J=19.1,2.3 \mathrm{~Hz}, 2 \mathrm{H})$, $7.1(\mathrm{~d}, J=19.1 \mathrm{~Hz}, 2 \mathrm{H}), 7.63(\mathrm{dd}, J=8.2,1.1 \mathrm{~Hz}, 2 \mathrm{H}), 7.73(\mathrm{~s}, 2 \mathrm{H}), 7.76(\mathrm{~d}, J=8.2 \mathrm{~Hz}, 2 \mathrm{H})$; ${ }^{13} \mathrm{C}$ NMR $\left(100 \mathrm{MHz}, \mathrm{CDCl}_{3}\right): \delta-4.0,123.9,126.5,126.9,128.5,133.6,136.0,145.4 ; \mathrm{MS} \mathrm{m} / \mathrm{z}$

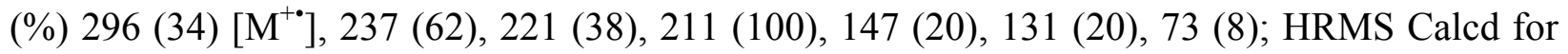
$\mathrm{C}_{18} \mathrm{H}_{24} \mathrm{Si}_{2}$ : 296.1417; Found: 296.1426; Calcd for $\mathrm{C}_{18} \mathrm{H}_{24} \mathrm{Si}_{2}$ : C, 72.90; H, 8.16. Found: C, 72.64; H, 8.32.

Naphthahlene-2,6-diyl-bis(trifluromethane sulfonate) (12). Into a cooled $\left(-15^{\circ} \mathrm{C}\right)$ solution of $11(5.0 \mathrm{~g}, 31.3 \mathrm{mmol})$ and $\mathrm{Et}_{3} \mathrm{~N}(26.0 \mathrm{~mL}, 188 \mathrm{mmol})$ in THF $(50 \mathrm{~mL})$ was added triflic anhydride $(16.5 \mathrm{~mL}, 97.7 \mathrm{mmol})$ and the solution was stirred for $0.5 \mathrm{~h}$ at the same temperature. Then the reaction mixture was diluted with $\mathrm{H}_{2} \mathrm{O}$ and extracted with $\mathrm{Et}_{2} \mathrm{O}$. The organic phase was washed with an ice cold aqueous $1 \% \mathrm{NaOH}$ solution and brine and dried with $\mathrm{Na}_{2} \mathrm{SO}_{4}$. After evaporation, the crude product was crystallized from $\mathrm{CHCl}_{3}-\mathrm{MeOH}$ to yield $12(11.1 \mathrm{~g}, 83 \%)$ as a pale brown solid; $\mathrm{mp} 84-85^{\circ} \mathrm{C}$.

2,6-Bis[(trimethlylsilyl)ethynyl]naphthalene (13). To a solution of 12 (10.7 g, $25.2 \mathrm{mmol}), \mathrm{CuI}$ $(0.238 \mathrm{~g}, 1.25 \mathrm{mmol})$ and $\mathrm{PdCl}_{2}\left(\mathrm{PPh}_{3}\right)_{2}(0.877 \mathrm{~g}, 1.25 \mathrm{mmol})$ in $\mathrm{Et}_{3} \mathrm{~N}(75 \mathrm{~mL})$ was added (trimethylsilyl)acetylene $(7.8 \mathrm{~mL}, 55.7 \mathrm{mmol})$. The reaction mixture was heated under reflux to give for $12 \mathrm{~h}$ and then cooled to $\mathrm{rt}$. The mixture was filtered and the filtrate was evaporated to dryness to give the crude product which was crystallized from $\mathrm{CHCl}_{3}$-hexane to yield $\mathbf{1 3}$ ( $7.5 \mathrm{~g}$, 93\%) as a pale brown solid. mp $120-121^{\circ} \mathrm{C}$; IR (KBr): $v$ 2962, 2869, 2156, 1498, 1260, 1250, 940, 899, 847, $759 \mathrm{~cm}^{-1}:{ }^{1} \mathrm{H}$ NMR (400 MHz, $\left.\mathrm{CDCl}_{3}\right): \delta 0.27$ (s, $\left.18 \mathrm{H}\right), 7.48$ (dd, J=8.4, $1.2 \mathrm{~Hz}$, $2 \mathrm{H}), 7.67$ (d, $J=8.4 \mathrm{~Hz}, 2 \mathrm{H}), 7.92$ (s, $2 \mathrm{H}) ;{ }^{13} \mathrm{C}$ NMR (100 MHz, CDCl3): $\delta-0.1,95.4,105.1$,

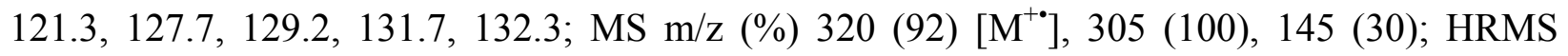
Calcd for $\mathrm{C}_{20} \mathrm{H}_{24} \mathrm{Si}_{2}$ : 320.1417; Found: 320.1407 .

2,6-(Bis-ethynyl)naphthalene (2). To a stirred suspension of $13(8.0 \mathrm{~g}, 25.0 \mathrm{mmol})$ in $\mathrm{MeOH}$ $(50 \mathrm{~mL})$ was added $\mathrm{K}_{2} \mathrm{CO}_{3}(0.62 \mathrm{~g}, 4.50 \mathrm{mmol})$ and stirring was continued for $6 \mathrm{~h}$ at $\mathrm{rt}$. Then the reaction mixture was filtered, and the filtrate was evaporated to yield the crude product which was crystallized from $\mathrm{CHCl}_{3}$-hexane to yield 2 (4.0 g, 91\%) as a pale brown solid; m.p. 138-139 ${ }^{\circ} \mathrm{C}$ (hexane); IR (KBr): v 3272, 2990, 2920, 2106, 1596, 1363, 1272, 1253, 886, 820, 705, 676, $627 \mathrm{~cm}^{-1} ;{ }^{1} \mathrm{H}$ NMR $\left(400 \mathrm{MHz}, \mathrm{CDCl}_{3}\right): \delta 3.17(\mathrm{~s}, 2 \mathrm{H}), 7.52(\mathrm{dd}, J=8.4,1.2 \mathrm{~Hz}, 2 \mathrm{H}), 7.71(\mathrm{~d}, J$ $=8.4 \mathrm{~Hz}, 2 \mathrm{H}), 7.96(\mathrm{~s}, 2 \mathrm{H}) ;{ }^{13} \mathrm{C} \mathrm{NMR}\left(100 \mathrm{MHz}, \mathrm{CDCl}_{3}\right): \delta$ 78.2, 83.7, 120.4, 127.8, 129.3,

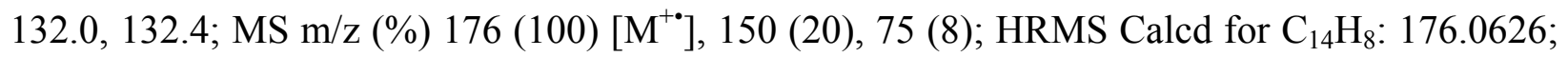
Found: 176.0623 .

Poly(2,6-divinylnaphthyl)dimethylsilylene (3). A mixture of 1 (296 mg, $1.0 \mathrm{mmol}), 2$ (176 mg, $1.0 \mathrm{mmol})$ and $\mathrm{RhCl}\left(\mathrm{PPh}_{3}\right)_{3}(4.6 \mathrm{mg}, 0.005 \mathrm{mmol})$ in $\mathrm{CH}_{2} \mathrm{Cl}_{2}(5 \mathrm{~mL})$ was heated under reflux for $10 \mathrm{~h}$. After cooling to $\mathrm{rt} \mathrm{MeOH}$ was added to precipitate the crude polymer, which was dissolved 
in $\mathrm{CHCl}_{3}$, and re-precipitated upon treatment with $\mathrm{MeOH}$. After filtration the solid was washed twice with $\mathrm{MeOH}$ and dried to yield 3 (230 mg, 61\%) as a yellow solid; $\mathrm{Mn}=2600$ (PDI: 2.5) ${ }^{1} \mathrm{H}$ NMR (400 MHz, $\mathrm{CDCl}_{3}$ ): $\delta 0.36$ (bs, $6 \mathrm{H}$ ), 6.65 (bd, $J \sim 19.0 \mathrm{~Hz}, 2 \mathrm{H}$ ), 7.11 (bd, $J \sim 19.0 \mathrm{~Hz}, 2$ H) $7.66-7.75(\mathrm{~m}, 6 \mathrm{H})$.

The other copolymer of $\mathrm{Mn}=4500$ (PDI: 3.3) was prepared as described above, by treatment of 1 (296 mg, $1.0 \mathrm{mmol}), 2$ (176 mg, $1.0 \mathrm{mmol})$ and $\mathrm{RhCl}\left(\mathrm{PPh}_{3}\right) 3(9.2 \mathrm{mg}, 0.01 \mathrm{mmol})$ in $\mathrm{CH}_{2} \mathrm{Cl}_{2}$ $(5 \mathrm{~mL})$. After work up it was yielded $(250 \mathrm{mg}, 53 \%)$ as a yellow solid.

\section{Acknowledgements}

The authors would like to thank the Ministry of Education and the National Science Council of the Republic of China for financial support.

\section{References and Notes}

1. (a) Hu S. S.; Weber W. P. W. Polym. Bull., 1989, 21, 133. (b) Ishikawa M.; Ni H.; Watanabe H.; Saheki Y. Organometallics 1987, 6, 1673. (c) Ohshita J.; Matsuguchi A.; Furumori K.; Hong R.-F.; Ishikawa M. Macromolecules 1992, 25, 2134. (d) Ohshita J.; Kanaya D.; Watanabe T; Ishikawa M. J. Organomet. Chem. 1995, 489, 165.

2. (a) Ohshita J.; Kanaya D.; Ishikawa M.; Koike T.; Yamanaka T. Macromolecules 1991, 24, 2106. (b) Corriu R. J. P.; Guerin C.; Henner B.; Kuhlmann T.; Jean A; Garnier F.; Yassar A., Chem. Mater., 1990, 2, 351. (c) Ohshita J.; Kanaya D.; Ishikawa M., J. Organomet. Chem. 1989, 369, C18. (d) Yuan C.-H.; West R. Appl. Organomet. Chem. 1994, 8, 423.

3. Corriu R. J. P.; Douglas W. E.; Yang Z. X.; Kaarakus Y.; Cross G. H.; Bloor D. J. Organomet. Chem. 1993, 455, 69.

4. (a) Burroughes J. H.; Gradley D. D. C.; Brown A. R.; Marks R. N.; Mackay K.; Friend R. H.; Burn P. L.; Holmes A. B. Nature 1990, 347, 539. (b) Greenham N. C.; Moratti S. C.; Bradley D. D. C.; Friend R. H.; Holmes A. B. Nature 1993, 365, 628. (c) Halls J. J. M.; Walsh A. C.; Greenham N. C.; Marseglia E. A.; Friend R. H; Moratti S. C.; Holmes A. B. Nature 1995, 376, 498.

5. (a) Ryu M.-K.; Lee S. M.; Zyung T.; Kim H. K. Polym. Mater. Sci. Eng. 1996, 75. (b) Adachi C.; Tautsui T.; Saito S. App. Phys. Lett. 1990, 56, 799. (c) Pope M.; Swenberg C. E., Electronic Process in Organic Crystals, Oxford U: Oxford, 1982. (d) Kido J.; Kohda M.; Okuyama K.; Nagai K. Appl. Phys. Lett. 1992, 61, 761. (e) Yang Z.; Sokolik I.; Karasz F. E. Macromolecules 1993, 26, 1188. (f) Kim D. J.; Kim S. H.; Lee J. H.; Kang S. J.; Kim H. K.; Zyung T.; Cho I.; Choi S. K. Mol. Cryst. Liq. Cry. 1996, 280, 391.

6. Kim H. K.; Ryu M.-K.; Lee S.-M. Macromolecules 1997, 30, 1236.

7. Chen R.-M.; Chien K.-M.; Wong K.-T, Jin B. Y.; Luh T.-Y. J. Am. Chem. Soc. 1997, 119, 
11321.

8. Chen ,R.-M.; Luh, T.-Y. Tetrahedron 1998, 54, 1197.

9. Luh, T.-Y.; Chen, R. M.; Deng, Z.; Lee, S. T. In Semiconductive Polymers, ACS Symp. Ser.; Hsieh, B. R.; Galvin, M.; Wei Y., Eds; ACS: Washington D. C., 1999; Ch. 23, p. 374.

10. Gao, Z.; Lee, C. S.; Bello, I.; Lee, S. T.; Chen, R.-M.; Luh, T.-Y.; Shi, J.; Tang, C. W. Appl. Phys. Lett. 1999, 74, 865.

11. Luh, T.-Y.; Liu, S.-T. In The Chemistry of Organosilicon Compounds, Rappoport, Z.; Apeloig, Y., Eds.; Wiley: Chicester, 1998; Vol. 2, p. 1793.

12. Luc, N.; Antony, B.; Marie, E.; Tran, H. D.; Jieping, Z. J. Org. Chem. 1999, 64, 7638.

13. Sandro, C.; Pier, G.; Enrico, M.; Giorgio, O. Tetrahedron Lett. 1986, 27, 3931.

14. Ni, Z.-J; Yang, P.-F.; Ng, D. K. P.; Tzeng, Y. L.; Luh, T.-Y. J. Am. Chem. Soc. 1990, 112, 9356.

15. Takahashi,S.; Kuroyama, Y.; Sonogashira, K.; Hagihara, N. Synthesis 1980, 8, 627

16. Zhao, H.; Neamati, N.; Mazumder, A.; Sunder, S.; Pommier, Y.; Burke, T. R.; Terrence, R. J. Med. Chem. 1997, 40, 1186.

17. van Tamelen, E. E.; Pappas, B. C. T. J. Am. Chem. Soc. 1971, 93, 6111.

18. Ando T.; Nakagawa M. Bull. Chem. Soc. Jpn. 1967, 40, 363.

19. Hanhela P. J.; Paul D. B. Aust. J. Chem. 1989, 42, 287. 